strated mark a step forward in the culture of mosquito tissues in vitro. I thank Dr. W. Trager of the Rockefeller Institute for his advice, and Mrs. Ch. Horak for hor help.

This investigation was supported by research grant 63-CDC-51-01 from the U.S. Public Health Sorvice, Bureau of State Services.

\section{J. Peleg}

Israel Institute for Biological Research,

$$
\text { Ness-Ziona. }
$$

1 Trager, W., Amer. J. Trop. Med., 18, 387 (1938).

${ }^{2}$ Peleg, J., and Trager, W., Amer. J. Trop. Med. Hyg., 12, 820 (1963).

${ }^{3}$ Trager, W., Ann. 'Trop. Med. Parasitol., 53, 473 (1959).

${ }^{4}$ Hayes, R. O., J, Econ. Entomol., 46, 624 (1953).

\section{Inability of Metabolizable Oils to Mimic Corpus Allatum Hormone Stimulation of Ovarian Development in Mosquitoes}

There has been considerable experimental evidence that the juvenile hormone, secreted by the corpus allatum, is responsible for the maintenance of the larval condition in immature insects and the initiation of ovarian develop. ment in the adult ${ }^{1,2}$.

Recontly, Larsen and Bodenstoin ${ }^{3}$ were able to show that a crude oil extract of cockroaches prepared after the method of Williarns induced ovarian development in anautogonous mosquitoes. Most of these extracts proved to be exceedingly toxic. Some of the mosquitoes died a few hours after injection, while others lived for several days. Tho oxtract initiated ovarian development in nonblood fed anautogenous Aëdes aegypti and Culex pipiens. Because of the toxicity of the preparation only a few insects survivod to show this effect, but the experiments domonstrated that the activating principle is not species specific. The ovarian development of anautogenous mosquitoes providos a sonsitive and simplo mothod for the bioassay of the juvenile hormone.

These experiments of Larsen and Bodenstein ${ }^{3}$ have rocontly boen criticizod by Gilbort and Schnoiderman ${ }^{5,6}$. The major criticisms were that "no evidence was offered to show that the extract prevented the larval tissue of any insoct from assuming its adult aspect", and thoy also suggested that there was no hormone effect present in the extract at all but that ovarian development in the mosquito was inducod by somo nutritive factor in tho oil Gilbert ${ }^{8}$, quoting unpublished data of Harman and Schneiderman, claims that "The possible nutritive role of tho insect oil itself cannot be excluded. Indood, injections of any metabolizable oil like peanut oil or insect oil will stimulate the ovarian development of pseudoallitectomized milkweed bugs". Yoeli and Mer ${ }^{7}$ elaim that the lipid-rich stroma of red blood cells contains some constituent necessary for the development of eggs in Anopheles. Gilbert and Schnoidorman ${ }^{5}$ infor that the experiments of Yoeli and Mer are further proof that ovarian dovelopmont in the mosquitoes was a result of oil nutrition rathor than a hormono.

Experiments have now been completed which show there is no gonadotrophic factor in peanut oil or hormonefroo insoct oil. Rnfinod poanut oil U.S.P. (Magnus, Moboe and Reynard) was injocted into 85 fomale mosquitoes (Table 1). The mortality was probably due to injoction-trauma rathor than any toxic offect of tho peanut oil. $\Lambda$ fter six days all the femalos wore killod and none of them showed any ovarian development boyond tho $24-48 \mathrm{~h}$ diapausestage of all unfed fomale mosquitoes. Whon the mosquitocs wero killed the drop of poanut oil was observed intact in the haemocoele and had no apparont effect on any of the mosquito tissues.

There remained the possibility that a hormono-froe cockroach oxtract oil might be more nutritious than peanut oil and thus bo capablo of inducing ovarian developmont. To eliminato any possibility of a nutritious oil inducing ovarian development a hormone-free cockronch extract oil was propared after the manner of Williams ${ }^{4}$, as Larson and Bodenstein ${ }^{3}$ prepared their extract in previous experiments. Adult cockroaches loss than $12 \mathrm{~h}$ after moulting and bofore tho tanning of the cuticlo wore usod to prepare this extract. This stage in the cockroach life-cycle was chosen to propare a hormone-free extract based on the work of Bodenstein and Sprague ${ }^{8}$ in which they were able to show that shortly before metamorphosis and up to $12 \mathrm{~h}$ after the last moult there is little or no allaturn hormono present in the organism. If any allatum hormone is present at this time it must be in very small amounts because the colleterial gland assay of Bodenstein and Sprague ${ }^{8}$ in nowly motumorphosed adults was essentially nogative.

The cockroach extract oil was injected into 55 adult female mosquitoes at least $24 \mathrm{~h}$ after emorgenco. As can be seen in Table 1, none of the mosquitoes showod any ovarian development at the end of six days. There was a fairly high mortality, which coincides with earlier work ${ }^{8}$ in which wo pointed out that tho crude cockroach oxtract was toxic, and only a few mosquitoes survived.

Table 1. Aëdes aegypti INJECTED WITH PRANUT OIr AND HORMONE-FRFF COCKROACH EXTRACT OIL FROM NEWLY METAMORPHOSED COCKROACHES, Periplaneta americana

(The cockroach oil extract was made from animals within $12 \mathrm{~h}$ of the last moult before the cuticle had tanned or hardened)

\begin{tabular}{|c|c|c|c|}
\hline & $\begin{array}{l}\text { No. mos- } \\
\text { quitoes } \\
\text { injected }\end{array}$ & $\begin{array}{l}\text { No. mos- } \\
\text { quitoes } \\
\text { survived }\end{array}$ & $\begin{array}{cc}\text { No. mosquitoes } \\
\% & \text { showing ovarian } \\
\text { mortality development } 6 \text { days } \\
\text { after injection }\end{array}$ \\
\hline $\begin{array}{l}\text { eanut ofl } \\
\text { ockroach extract oil }\end{array}$ & $\begin{array}{l}85 \\
55\end{array}$ & $\begin{array}{l}74 \\
43\end{array}$ & $\begin{array}{l}13 \\
22\end{array}$ \\
\hline
\end{tabular}

$\begin{array}{lllll} & 85 & 74 & 13 & 0 \\ \text { Cockroach extract oil } & 55 & 43 & 22 & 0\end{array}$

Gilbert and Schneiderman ${ }^{5,6}$ referrod to the work of Yoeli and Mer in attempting to substantiate their contention that "some metabolizable oil" was responsible for ovirian development. Blood is a good nutritional substrate for the formation of yolk material; but by a series of ligation, docapitation, extirpation and implantation experiments it was shown ${ }^{3,0}$ that ogg dovelopmont in mosquitoes is under hormonal control. The triggering mechanism for the initiation of ovarian development appears to be gut distension. Day ${ }^{10}$ showed that when washed erythrocytes were fed to mosquitoes, being particulato in nature, thoy did not enter the diverticula but went to the mid-gut where thoy could form a coagulum and initiato ovarian development. The same is true in the exporiments of Yooli and Mor ${ }^{7}$. Hormone secretion necessary for ovarian dovelopment in mosquitoes is triggered, probably by gut distension, but the number of eggs doveloped is undoubtedly related to the amount of nutrient available in the mid-gut. Ovarian dovelopment in mosquitoes will not be initiated by injections into the haemocoole of whole blood, poanut oil, or cockroach extract oil which is freo of hormono.

There is adequate experimental evidence that allatum hormone is present and is activoly secreted in cockroaches 8,11

This work was supported by U.S. Public Hoalth Sorvice grant 1-T1-GM-1076.

Department of Entomology,

Univorsity of Tllinois, Urbana.

2 Wigglesworth, V. B, J. Exp. Biol., 25, I (1948),

${ }^{2}$ Chen, D. H., Robbins, W. H., and Monroe, R. T., Experientia 18, 577 (1962).

3 Larsen, J. R, and Bodenstein, D, J. Exp, Znol., 140, 343 (1959).

* Williams, C., Nature, 178, 212 (1956).

GHlbert, L. I., and Schnelderman, I., A., Amer, Zool., 1, 11 (1961).

- Gilbert, X. I., in Comparative Endocrinology, edit. by von Euler, U. S., and Heller, H., 2, 1 (Academic Press, New York, 1963),

7 Yoeli, M. and Mer, G. G., Trans. Roy. Soc. Trop. Med. Iug., 31, 437 (1938).

Bodenstein, D., and Sprague, I. B., J. Exp. Zoot., 142, 177 (1959).

- Tarscn, J. R., Science, 127, 587 (1058).

${ }^{10}$ Day, M. F., A ust. J. Biol. Sci., 7, 515 (1054).

11 Wigglesworth, V. H., J. Wxp, Biot, 29, 820 (1952). 